\title{
Plastik Parçaların Montajında Kullanılan Geçmeli Bağlantılar İçin Takma Çıkarma Yüklerinin İki Boyutlu Sonlu Elemanlar Analizleri Yardımıyla Belirlenmesi
}

\author{
İlker Bahar ${ }^{* 1}$, Nejdet Şen²
}

\section{ÖZ}

Günümüzde üretilen araçların hemen hemen hepsinde iç döşeme, araç dış stili, kapılar vb. gibi alt montaj gruplarında yer alan plastik parçaların montajı için vidalama ve yapıştırmanın yanında çoğunlukla esneyebilen ve takıldığında kilitlenen geçmeli tırnak ya da buton bağlantıları kullanılmaktadır. Bu tip bağlantıların kullanılmasıyla, ilgili plastik parça sökülebilir ve değiştirebilir hale gelmektedir. Tam da bu noktada, tırnak ya da buton bağlantıları için montaj ve demontaj esnasında oluşan takma-çıkarma yüklerinin hesabı, tasarım ve sonrasındaki doğrulama ile kullanım ömrü için en önemli parametre olmaktadır. Farklı tasarım alternatiflerinin en az prototip ve en hızlı şekilde değerlendirilebilmesi için sonlu elemanlar yöntemlerinden faydalanılmaktadır. Bu çalışmada, araç iç döşemesinde kullanılan plastik bir kaplamaya ait tırnak bağlantısı için takma çıkarma yükleri iki boyutlu sonlu elemanlar analizleri yardımıyla belirlenmişsir.

Anahtar Kelimeler: Takma-çıkarma yükü, statik analiz, sonlu elemanlar metodu, tırnak ve buton bağlantıları

\section{Determination of Mounting - Dismounting Loads via Two- Dimensional Finite Element Methods for Snap - Fit that Used to Assemble Plastic Parts}

\begin{abstract}
Almost all vehicles that manufactured in present, snap-fit which are so flexible and can be locked after insertion are used for mounting sub-assemblies such as internal trim, external trim, closures etc. By using this type connection, plastic parts of sub-assemblies can be mounted or dismounted. At this point, calculation of loads while mounting-dismounting become the most important variables for design and verification after design in lifetime cycle. In this study, mounting - dismounting load calculated by using two dimensional (2D) finite elements methods for a snap - fit connection which used in a vehicle's covering plastic parts of internal trim.
\end{abstract}

Keywords: Mounting-dismounting loads, static analysis, finite elements methods, snap-fit

\footnotetext{
* İletişim Yazarı

Geliş/Received : $\quad 24.06 .2019$

Kabul/Accepted : : 17.09.2019

1 TOFAŞ Türk Otomobil Fabrikası AR-GE Merkezi, Bursa - ilker.bahar@tofas.com.tr ORCID: 0000-0002-5636-6031

2 TOFAŞ Türk Otomobil Fabrikası AR-GE Merkezi, Bursa - nejdet.sen@tofas.com.tr ORCID: 0000-0002-5597-9362
} 


\section{GİRIŞ}

Plastik parçaların montajında kullanılan geçmeli bağlantılar, tırnak veya buton, basit yapıdaki tasarımlarının yanında ekonomik olmaları ve farklı parçaları en hızlı yoldan birbirine bağlamaları ile ön plana çıkmaktadır. Geçmeli tırnak bağlantıları Şekil 1'de görüldüğü gibi farklı sayılardaki çok çeşitli tiplere sahip olmasına rağmen tek bir prensip ile çalışmaktadır: çıkıntılı olarak tasarlanan ve üretilen tırnak, montaj esnasında esneyerek birleştireceği parça üzerindeki boşluğuna girerek eski haline dönmektedir $[1,8,9]$.

Geçmeli bağlantılar için yapılan tasarımlar sayesinde montajı yapılan iki parça, zarar görmeksizin birbirine bağlanıp sökülebilir hale gelmektedir. Montaj operasyonundan sonra bağlantı üzerindeki gerilmelerin ortadan kalkmasıyla birlikte, yapı montaj başındaki ön yüksüz haline geri dönmektedir. Bu durum tırnak ya da buton bağlantılarının defalarca kullanımına olanak sağlamaktadır. Montaj ve demontaj işlemlerinin kolayca yapılabilmesi adına bu bağlantılar için takma-çıkarma yüklerinin hesaplanması ve tasarımın buna göre geliştirilip üretilmesi gerekliliği ortaya çıkmaktadır $[2,7,10]$.

Geçmeli tırnak veya buton bağlantılarının kullanımı, ilgili birleşme yüzeyinin yapı ve şekli ile daha önceki paragrafta önemi vurgulanan takma-çıkarma yüklerinin hesabıyla yakından alakalıdır. Diğer bir deyişle takma veya çıkarma yükleri, montajlanacak

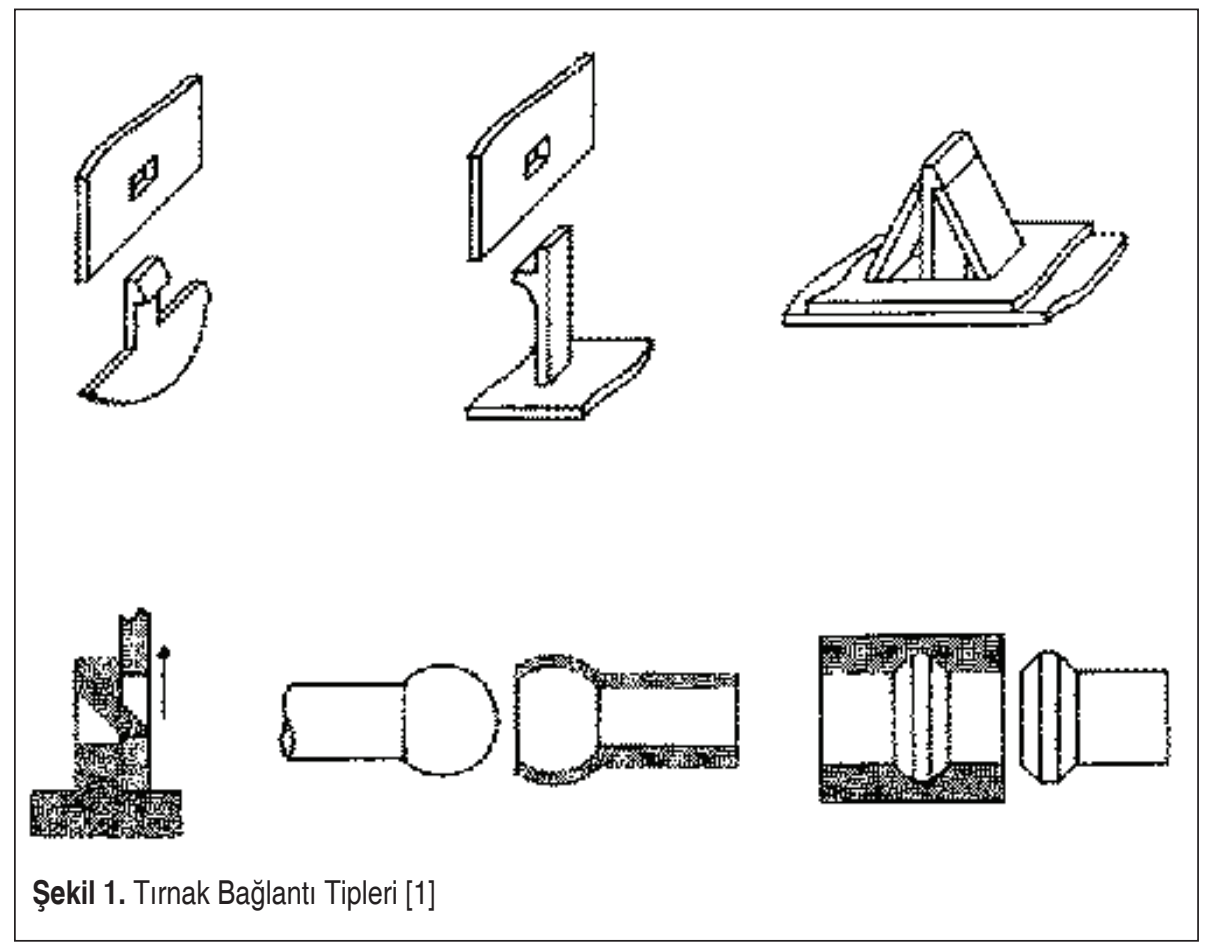


plastik parçalardaki tırnak ve karşılığının temas ettiği noktayla orantılıdır ki plastik parçalardaki boyutsal tolerans ve hatalar göz önüne alındığında bu noktanın orantısal önemi daha da artmaktadır. Tasarımcının, plastik parçaların montajı esnasında önyüklemenin sağlanabilmesi için tırnak ve karşılığını girişimli şekilde modellemesi gerekmektedir. Girişimin yetersiz olması montaj boşluğuna ve dolasıyla herhangi bir titreşim esnasında da ses problemine sebep olurken gereğinden fazla girişim ise; montaj zorluğuna sebep olmakta ve aynı zamanda geçmeli bağlantının takma veya çıkarma esnasında kırılıp işlevini yitirmesine sebep olabilmektedir. Girişim miktarı, Şekil 2'de görüldüğü gibi araç parçalarında kullanılan geçmeli bağlantılar ile elektronik sektöründe kullanılan plastik tırnakların montajında beklenen kalite seviyesi nedeniyle önem arz etmektedir. Buradan hareketle Chen ve Lan, çalışmalarında bahsi geçen birleşme yüzeyi ve tırnak ile karşılığının temas noktası iyileştiren sabit takmaçıkarma yüküne sahip bir geçmeli tasarımına yer vermişlerdir [3].

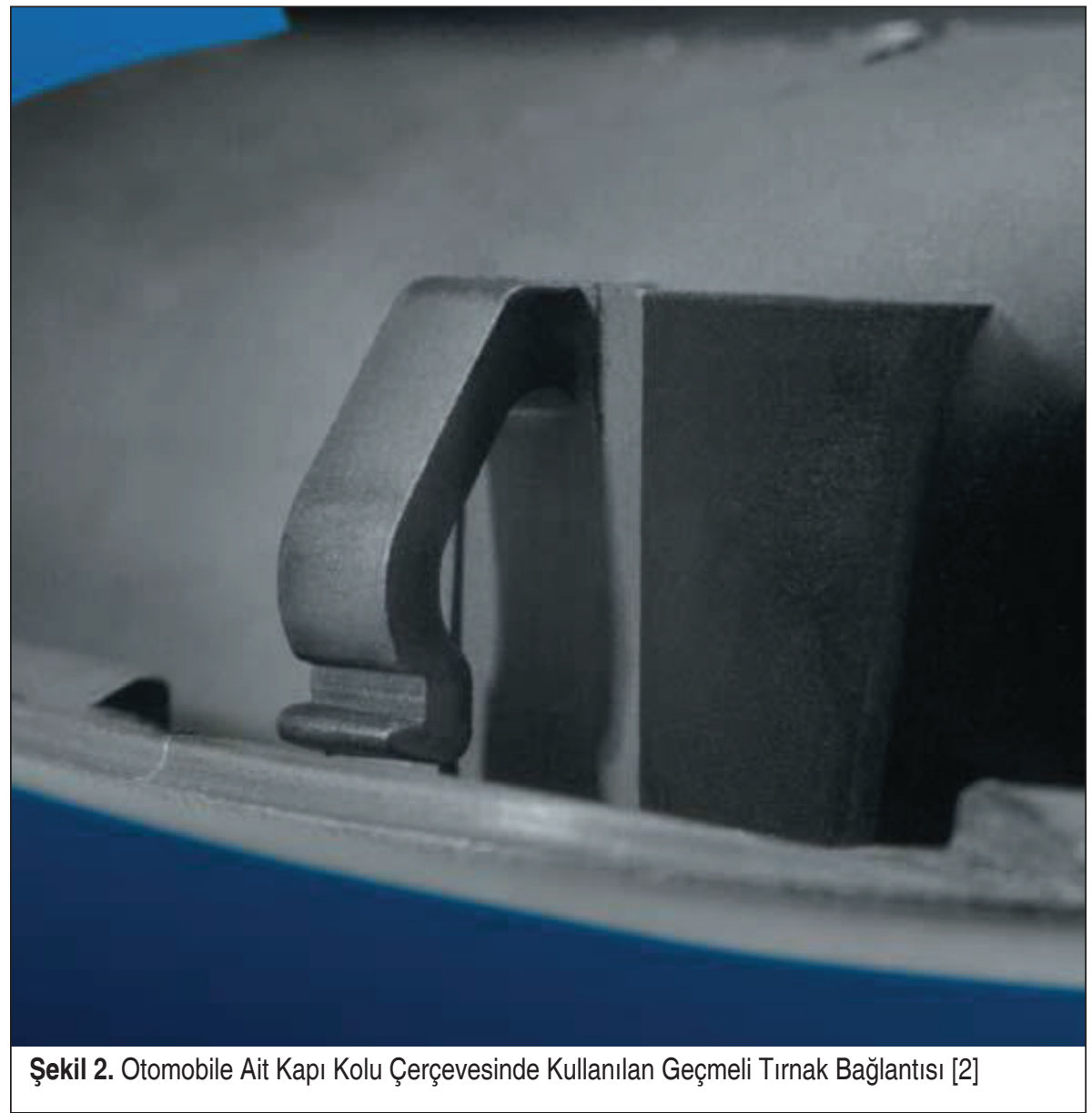


Kulkarni ve arkadaşları, Hyperworks ve çözücülerini kullanarak sonlu elamanlar metotları yardımıyla tasarım gereksinimlerini karşılayan bir tırnak bağlantısı tasarımı üzerine çalışma yapmışlardır. Çalışmaları sonucunda; tasarımda kullanılan tırnak açısının, tırnak genişliği ile kalınlığının ve keskin köşelerdeki yuvarlatılmış alanların, parçalar ve geçmeli bağlantı üzerindeki gerilme dağılımına doğrudan etkilediğini görmüşlerdir [4].

Üç tırnak analizlerine ait simülasyonlarının en önemli adımı parçalar arası temasların tanımlanıp çözümlenmesidir. Temasların yakınsaması problemin çözüm süresini uzatarak zaman kaybına neden olmaktadır. Diğer yandan bir boyuta indirgenmiş analizler, çözüm süresini kısaltabilmekte ancak; temaslar için bu analiz tipi yetersiz kalmaktadır. Ayrıca kompleks yapıdaki tırnak geometrileri bir boyutlu analiz simülasyonlar yardımıyla tam olarak modellenememektedir. Jorabchi ve Suresh, çalışmalarında tırnak analizlerinde kullanılmak üzere "İki dünyanın da en iyisi" diye tabir ettikleri doğrusal olmayan cebirsel yönde zaman kazandırıcı bir metot sunmuşlardır [5].

Bu çalışmada, araç iç döşemesinde kullanılan plastik bir kaplamaya ait tırnak bağlantısı için takma çıkarma yükleri sonlu elemanlar yardımıyla belirlenmiştir. Tasarımdan alınan katı model yardımıyla tırnak bağlantısının iki boyutlu matematik modeli kurulmuştur. Bu matematik model yardımıyla analizler koşturularak tırnağa ait takma-çıkarma yükleri tespit edilmiştir. Sonlu elemanlar modelinin iki boyutlu ortamda kurulması, üç boyutlu yapılan analizlere göre çözüm süresini azaltarak zaman kaybını en aza indirmiştir. Ayrıca yapılan prototip sayısı minimum seviyeye çekilerek en az maliyetle tasarımın üretilmesi için sanal ortamda doğrulamalar yapılmıştır.

\section{MATERYAL VE METOD}

\subsection{Malzeme Özellikleri}

Çalışmada kullanılan araç iç döşemesine ait bir parçada yer alan geçmeli tırnak bağlantısı Polipropilen (PP) malzemesi ile üretilmektedir. Polipropilen, başta otomotiv sanayisinde olmak üzere tekstil, ambalaj, etiketleme ve paketleme sektörüne kadar hatta ve hatta günlük hayatın her noktasında, mutfak eşyaları, banyo gereçleri, elbise askıları vb. gibi, çok geniş kullanım alanına sahip yarı sert, şeffaf, kolay şekillendirebilen, ekonomik ve asit ile bazlara karşı dayanıklı bir polimerdir. Yorulmaya karşı çok dirençlidir, düşük maliyet sebebiyle de ticari kullanım alanı oldukça yaygındır. Darbe sönümü yüksektir, aynı zamanda çok iyi elektrik yalıtımı sağlamaktadır $[6,11,12]$.

Yapılan sonlu elemanlar analizlerinde, malzemenin oda sıcaklığındaki elastisite modülüne, poisson oranına ve gerilme-şekil değiştirme eğrisine ihtiyaç duyulmuştur. Polipropilene ait bazı genel, mekanik ve termal özellikler Tablo 1'de verilmişstir. Analiz yapılırken elastik olarak en kötü durumdaki özellikleri dikkate alınarak modellenen bu malzemenin plastik bölgedeki davranışı ise; tedarikçiden alınan ve çekme testine göre oluşturulmuş gerilme-şekil değiştirme üzerinden türetilerek elde edilmişstir. 
Tablo 1. Polipropilen Malzeme Özellikleri [6]

\begin{tabular}{|l|c|c|}
\hline Malzeme Özelliği & Birim & Değer \\
\hline Özgül Ağırlık & $\mathrm{kg} / \mathrm{m}^{3}$ & 920 \\
\hline Poisson Oranı & - & $0,35-0,40$ \\
\hline Çekme Dayanımı & $\mathrm{GPa}$ & $0,03-0,06$ \\
\hline Elastisite Modülü & $\mathrm{GPa}$ & $1,4-1,8$ \\
\hline Kopma Uzaması & $\%$ & $>50$ \\
\hline Isıl Genleşme Katsayısı & ${ }^{\circ} \mathrm{C}^{-1}$ & $1,6 \times 10^{-4}$ \\
\hline
\end{tabular}

\section{2 İki Boyutlu Sonlu Elemanlar Modelinin Oluşturulması}

Tasarımcı tarafından hazırlanan katı geometri modeli, sonlu elemanlar matematik modelinin kurulacağı program içerisine alınarak üzerindeki gereksiz delik, yuvarlatma vb. gibi geometrik unsurların temizliği yapılmıştır. Diğer yandan takma-çıkarma yükü için yapılan analizler, sadece lokal bir bölgeyi etkilediğinden katı geometrik modelin kesilerek küçültülmesi analiz süresi açısından fayda sağlamıştır.

Katı geometrik modelin temizlemesinin ardından iki boyutlu sonlu elemanlar matematik modelinin oluşturulması amacıyla katı model üzerinde farklı kalınlıkları temsilen gerekli bölme işlemleri yapılmıştır. Sonrasında, düzlem şekil değiştirme prensibi gereğince Şekil 3'te görüldüğü gibi XY eksenine pozisyonlanıştır. Böylece sonlu elemanlar modelindeki eleman normalleri + z eksenine bakacaktır [13,14].

Sonlu elemanalar matematik modelini oluşturmak için kullanılacak ortalama eleman boyutu, en küçük geometrik unsurun büyüklüğü baz alınarak 0,05 mm olarak belirlenmiştir. Şekil 3 'te görüldüğü gibi kritik olan temas bölgelerinde eleman boyutu, eleman

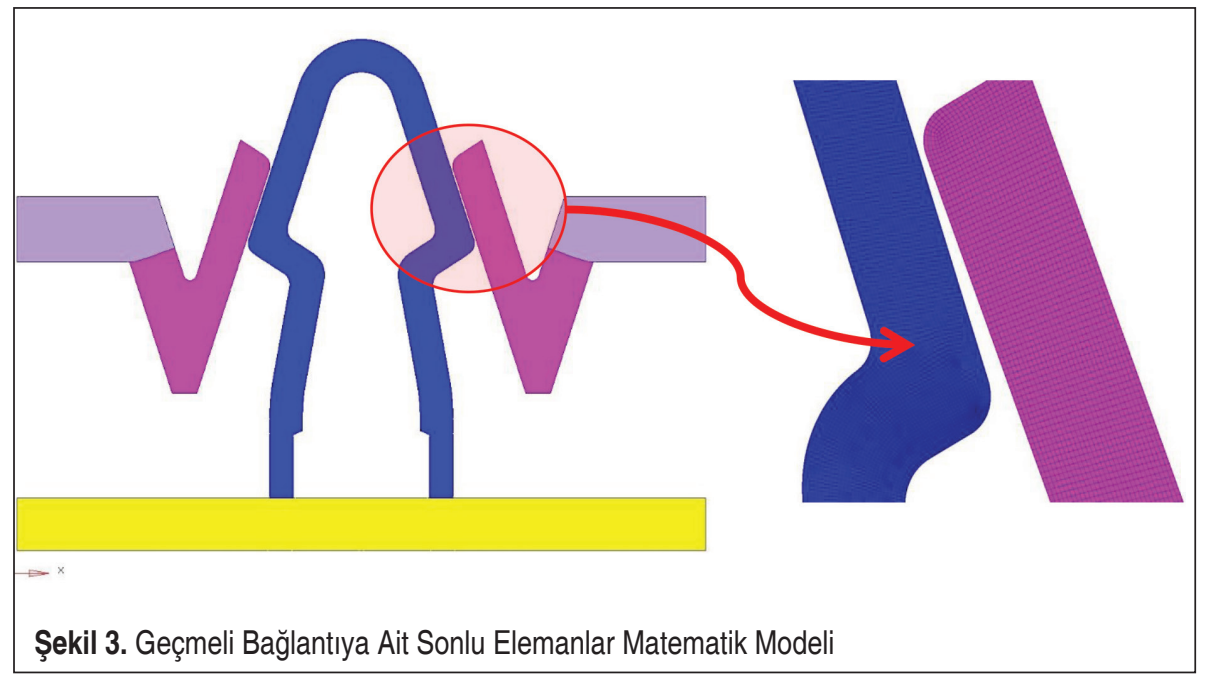


kalitesi kaybedilmeyecek şekilde küçültülmüştür. Analiz açısından daha az önem arz eden bölgelere doğru ilerledikçe eleman boyutları uygun geçiş kuralları ve kalite kriterleri kullanılarak büyütülmüştür. Tablo 2'de sonlu elemanalar matematik modelinde kullanılan elemanlara ait kalite kriterleri görülmektedir. Bunlara ek olarak matematik model oluşturulurken z ekseni doğrultusundaki tüm kalınlıklar katı geometrik model baz alınarak Şekil 3 'te görüldüğü gibi farklı renklerin temsil ettiği gibi değişken şekilde tanımlanmıştır. Çünkü; iki boyutlu sonlu elemanlar kullanılarak oluşturulan matematik modellerde en önemli nokta model üzerindeki kalınlıkların ilgili değişken kesit sınırlarına göre doğru şekilde tanımlanmasıdır. Aksi takdirde sonuçların gerçek cevaplarla uyumundan bahsedilmesi pek mümkün olmayacaktır.

Tablo 2. Matematik Modele Ait Eleman Kalite Kriterleri

\begin{tabular}{|l|c|c|}
\hline Kalite Kriteri & Mevcut Değer & Kriter Değeri \\
\hline Eleman Sayısı & 40201 & - \\
\hline Düğüm Sayısı & 41753 & - \\
\hline Maksimum Çarpııma & 0,00 & $\leq 15,00$ \\
\hline En/Boy Oranı & 2,41 & $\leq 3,00$ \\
\hline Keskinlik & 42,07 & $\leq 45,00$ \\
\hline Dörtgensellik & 0,68 & $\geq 0,60$ \\
\hline
\end{tabular}

\subsection{Yükleme ve Sınır Şartları}

Sonlu elemanlar matematik modeli oluşturulmasının ardından analizin çözdürülmesi için gerekli yükleme ve sınır şartlarının belirlenmesi gerekmektedir. Öncelikle hareketli olan tırnak parçası takma pozisyonuna uygun şekilde geriye çekilmiştir. Sonrasında Şekil 4'te görüldügü üzere hareketli tırnak parçası üzerinde yer alan siyah alan ile işaretlenmiş rijit eleman üzerinden öteleme miktarı kadar zorlanmış deplasman, hareket ekseni doğrultusunda pozitif ve negatif yönde olmak üzere iki ayrı yükleme adımında uygulanmıştır. Rijit elemanın deplasman uygulama yönündeki öteleme hareketi serbest bırakılırken diğer tüm yönlerdeki öteleme ve dönme hareketleri kısıtlanmıştır.

Sabit tırnak parçası ise; yine Şekil 4’te görüldüğü üzere araç gövdesi ile birleştiği kırmızı alanla işaretlenmiş ortak kesişim yüzeylerindeki düğümlerden ankastre olacak şekilde tutularak tüm öteleme ve tüm dönme yönündeki hareketleri hem takma hem de çıkarma adımında kısıtlanmıştır.

Yükleme ve sınır şartlarına ek olarak Şekil 5'te görülen kırmızı renkteki tüm elemanlar arasında ve elemanların kendi içinde sürtünmeli temas tanımı yapılmıştı. 


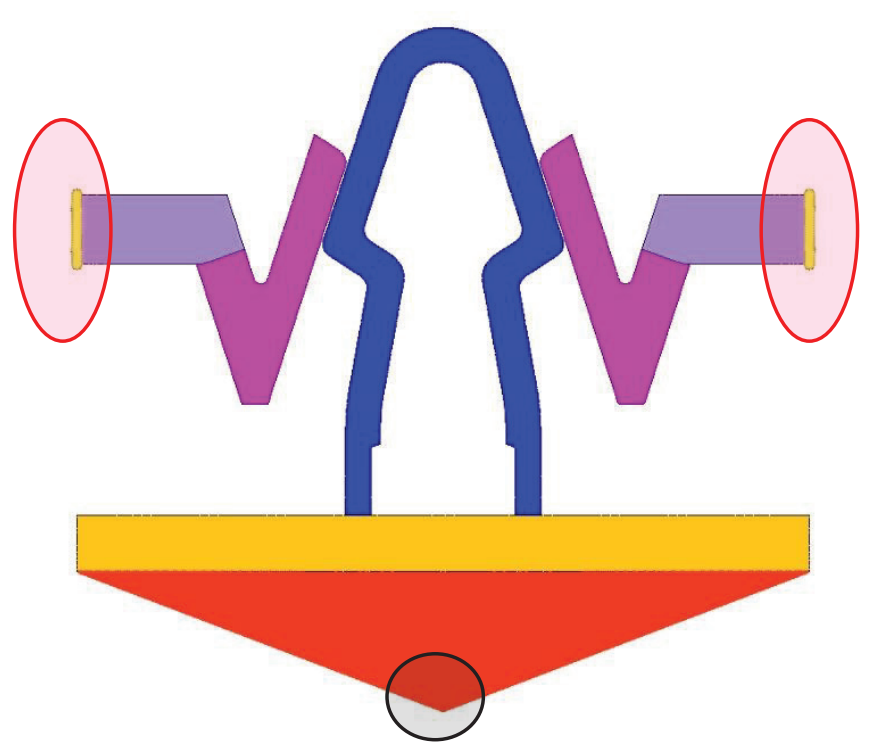

Şekil 4. Sonlu Elemanlar Matematik Modeli İçin Yükleme ve Sınır Şartlarının Belirlenmesi

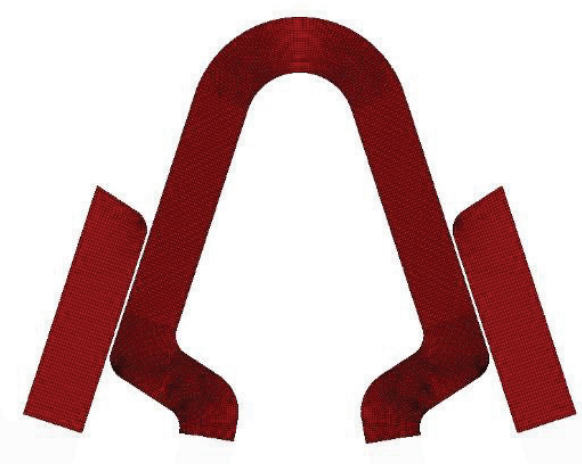

Şekil 5. Sonlu Elemanlar Matematik Modeli İçin Temas Bölgelerinin Belirlenmesi

\subsection{Sonlu Elemanlar Analizleri}

Yapılan sonlu elemanlar analizlerinde takma ve çıkarma yükleri deplasman miktarına karşılık ölçülen reaksiyon kuvvetleri yardımıyla tespit edilmiştir. Tırnak üzerindeki gerilme dağılımı incelenerek maksimum şekil değiştirmenin sınırlar altında kalıp kal- 
madığ 1 kontrol edilmiştir. Böylece takma veya çıkarma esnasında tırnakta herhangi bir kırılmanın meydana gelip gelmeme ihtimali araştırılmıştır.

Şekil 6' da görüldüğü gibi yükleme durumunda tırnak üzerinde oluşan maksimum gerilme $A$ MPa mertebesindedir ve sabit olan iç döşeme parçasının boyun bölgesindeki yuvarlatma kısmında yoğunlaşmıştır. Ayrıca takılma sonucunda oluşan hareketli tırnak ve sabit parça oluşan kalıcı deformasyon Şekil 6 üzerindeki geometri çizgileri yardımıyla net bir şekilde görülebilmektedir. Maksimum kalıcı şekil değiştirme miktar1 \%B mertebesindedir.
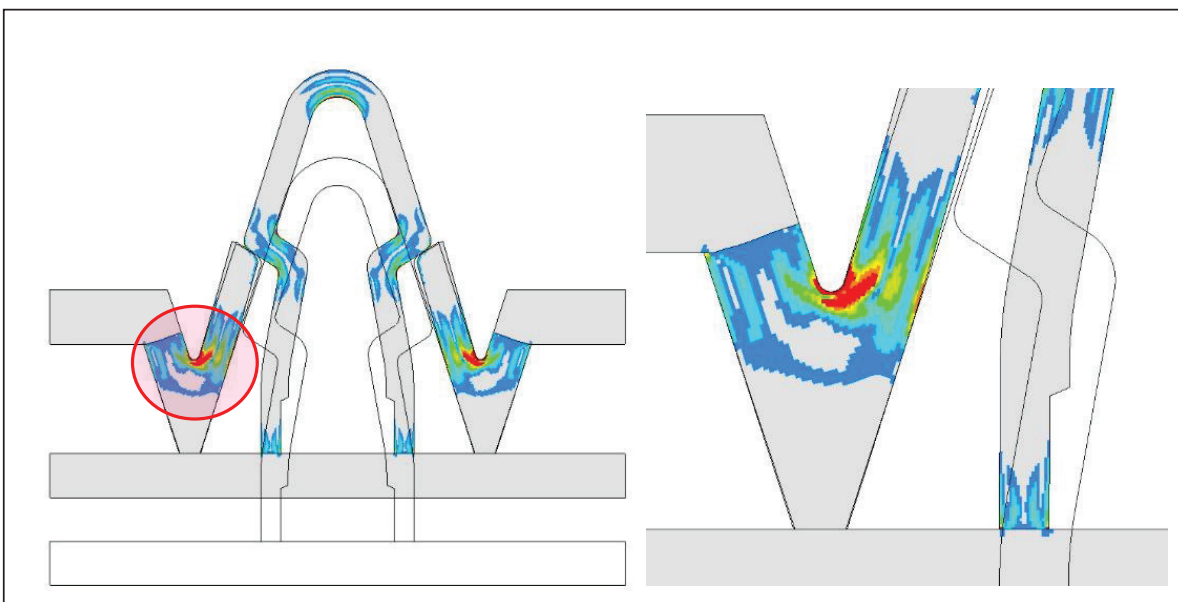

Şekil 6. Yükleme Durumunda Oluşan Maksimum Gerilme Dağııımı ve Kalıcı Şekil Değiştirme
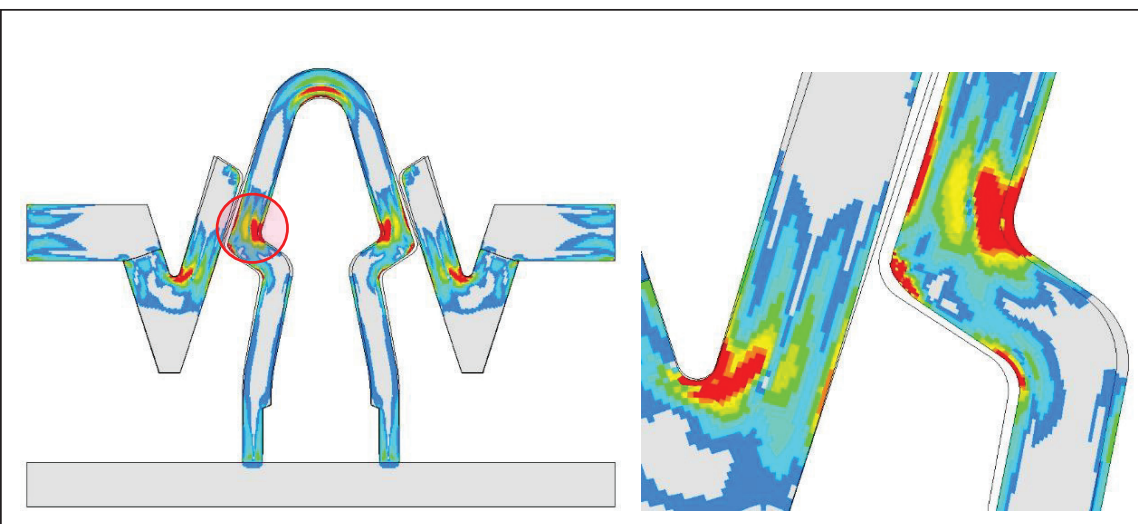

Şekil 7. Çıkarma Durumunda Oluşan Maksimum Gerilme Dağılımı ve Kalıcı Şekil Değiştirme 
Şekil 7'de ise; çıkarma durumunda tırnak üzerinde oluşan maksimum gerilme $1,1 \mathrm{~A}$ MPa mertebesindedir ve hareketli olan tırnak parçasının esneyen kısımdaki yuvarlatmada yoğunlaşmıştır. Ayrıca çıkarma sonucunda oluşan hareketli tırnak ve sabit parça oluşan kalıcı deformasyon Şekil 7 üzerindeki geometri çizgileri yardımıyla net bir şekilde görülebilmektedir. Maksimum kalıcı şekil değiştirme miktarı \%15,2B mertebesindedir.

Gerilme ve kalıcı şekilde değiştirme sonuçlarının haricinde çalışmanın asıl amacı olan takma ve çıkarma yüklerinin tayini için reaksiyon kuvvetlerinden faydalanılmıştır. Tırnağa ait takma ve çıkarmadaki reaksiyon kuvvetlerinin uygulanan deplasmana göre değişimimi Şekil 8'de grafiksel olarak gösterilmiştir. Takma esnasında maksimum olarak $f \mathrm{~N}$ seviyesine kadar gözlemlenen reaksiyon kuvveti, tırnağın nominal pozisyonuna geldiği andan itibaren reaksiyon kuvvetinın azalıp sıfıra indiği ve sonrasında vektörel olarak yön değiştiği gözlemlenmiştir. Çıkarma esnasında ise, gözlenen maksimum reaksiyon kuvveti 6,42f $\mathrm{N}$ olarak tespit edilmiştir. Ayrıca, takma ve çıkarma hareketi sonucunda oluşan maksimum kalıcı şekil değiştirmelerin tırnak bağlantısını kıracak seviyelere gelmediği tespit edilerek tırnağın işlevini yitirmediği görülmüştür.

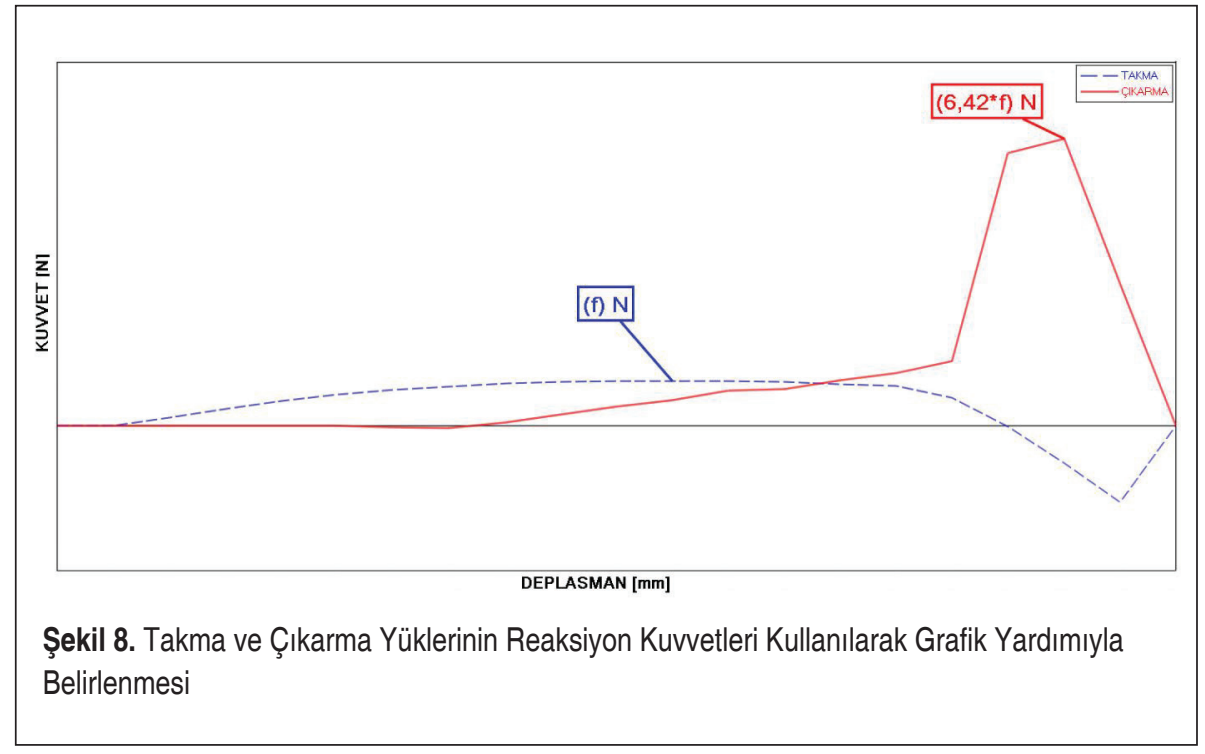

\section{SONUÇLAR VE TARTIŞMA}

$\mathrm{Bu}$ çalışmada, araç iç döşemesinde kullanılan plastik bir kaplamaya ait polipropilen malzemesinden üretilmiş tırnak için takma çıkarma yüklerinin hesabı iki boyutlu sonlu elemanlar modeli yardımıyla tespit edilmiştir. Katı model yardımıyla tırnağa ait iki boyutlu sonlu elemanlar matematik kurulmuştur. Sonrasında sınır ve yükleme şartları belirlenmiş ve takma çıkarma yüklerinin reaksiyon kuvvetlerinden türetilerek 
tespiti için doğrusal olmayan sonlu elemanlar analizleri koşturulmuştur. Düzlem şekil değiştirme prensibine göre oluşturulan iki boyutlu sonlu elemanlar modeli, üç boyutlu modele göre çözüm süresini ciddi derecede azaltarak zaman kaybını en aza indirmiştir. Bu metot, literatürdeki benzer çalışmalarından yaşanan çözüm yakınsama ve kontak sıkıntılarını çözerek kısa zamanda çözüm vermesi gibi yönleriyle ayrılmaktadır. Çözüm sürelerinin en aza indirilmesi, farklı alternatiflerin denenmesine ve değişken tasarımlar yardımıyla optimum çözümlerin ortaya çıkarılmasına neden olmuştur.

Ek olarak yapılacak olan prototip sayısı, sonlu elemanlar ortamında yapılan deneme ve doğrulamalar sayesinde minimum seviyeye çekilerek en az sayıda en az maliyetle tasarımın üretilmesi sağlanmıştır.

\section{KAYNAKÇA}

1. Bayer, Material Science, Snap-Fit Joints for Plastics - A Design Guide.

2. BASF, Technical Expertise, Snap - Fit Design Manual.

3. Yi-Ho Chen and Chao-Chieh Lan. 2012. "Design of a constant-force snap-fit mechanism for minimal mating uncertainty", Mechanism and Machine Theory, 55, 34-50.

4. Kulkarni V., Musale G., Vallurupalli S. 2017. "Effective Snap-Fit Design Using RADIOSS", Tata Technologies, Simulation Driven Innovation, 1-7.

5. Jorabchi K., Suresh K. 2009. "Nonlinear Algebraic Reduction for Snap-Fit Simulation", Journal of Mechanical Design, 131, 061004-1- 061004-8.

6. Şirin, K., Doğan, F., Çanlı, M., Yavuz M. 2013. "Mechanical properties of polypropylene (PP)+highdensity polyethylene (HDPE) binary blends: Nonisothermal degradation kinetics of PP+HDPE (80/20)", Blends. Polym. Advan. Technology, 715-722.

7. Anthony F. Luscher. 1997. "An investigation into the performance of cantilever hook type integral attachment features", In 1996 Design Engineering Technical Conference andComputers in Engineering Conference, ASME.

8. LloydWang, Gary Gabriele, and Anthony F. Luscher. 1995. "Failure analysis of a bayonet \& finger snap fit", In Proceedings of the Society of Plastics Engineers Annual Technical Conference (ANTEC).

9. Paul Bonenberger, 1995, “A new design methodology for integral attachments", In Proceedings of the Society of Plastics Engineers Annual Technical Conference (ANTEC).

10. U. Mohr-Matuschek and W. Michaeli. 1995. "Statistical experiment design for the optimization of snap-fit hinges by finite element analysis", In Proceedings of the Society of Plastics Engineers Annual Technical Conference (ANTEC).

11. B. Bader and R. Koch. 1994. "Numerical simulation of snap-in and snap-out processes of ball snap-fits", Computational Material Science, 3:125-134.

12. Gerald G. Trantina and Mark D. Minnichelli. 1987. "The effect of nonlinear material behavior on snap-fit design", In Proceedings of the Society of Plastics Engineers 45th Annual Technical Conference (ANTEC '87), pages 438-411, Los Angeles, CA.

13. Abaqus, Analysis User's Guide v6.13.

14. Altair Hyperworks, Desktop Help v2017.2.3. 